\title{
Incidence of Bacteriuria in Adult Renal Stone Patients Having Ureteric Stents and Undergoing Extracorporeal Shock Wave Lithotripsy
}

\author{
ABDULAZIZ AL-AMRI, F.R.C.Sc.*; FATIH EL-RAHMAN O. BABIKER, M.D.**; \\ MOHAMMED RASHID, M.D.** and ABDULMAJEED AYDH, M.D.** \\ The Department of Surgery, College of Medicine, King Khalid University* and The Department of Urology, \\ Aseer Central Hospital**, Abha, Saudi Arabia
}

\begin{abstract}
Background: To evaluate the effect of Extracorporeal Shock Wave Lithotripsy (ESWL) on the incidence of bacteriuria in patients with $\mathrm{JJ}$ stents who had sterile urine prior to ESWL.

Aim of Study: This study aimed to evaluate the effect of ESWL on the incidence of bacteriuria in patients with JJ stents who had sterile urine prior to ESWL.

Material and Methods: The study was conducted between January and August 2015 in Aseer Central Hospital, Abha, Saudi Arabia. We prospectively recruited 126 patients who had JJ stents previously inserted for renal or ureteral stones. Elderly patients and those with chronic medical diseases and other risk factors were excluded. All the patients had negative urine culture just before ESWL. Urine cultures were done twice, immediately after ESWL and two weeks later to detect the presence of bacteriuria. Those who had one or two positive cultures for bacterial growth were labeled to be having bacteriuria after ESWL, while those with negative cultures were labeled as negative for bacteriuria.
\end{abstract}

Results: Out of 126 patients with JJ stents, $20.6 \%$ developed bacteriuria after ESWL. The incidence of bacteriuria in females was higher than males $(p=0.002)$. Duration since JJ stent insertion (54.3 \pm 11.4 days) and the number of JJ stents were found to be significantly associated with positive bacteriuria ( $p<0.001$ for both). Number and size of stones were also associated with positive bacteriuria after ESWL $(p=0.009$ and $p<0.001$, respectively).

Conclusions: Incidence of bacteriuria in patients with renal stones with ureteric stents undergoing ESWL was 20.6\%, which was comparable to that of patients with ureteric stents who did not undergo ESWL. Therefore, antibiotic prophylaxis in patients with ureteric stents undergoing ESWL may not be necessary, except in certain cases (i.e., female gender, several stents and their prolonged duration, as well as the multiple stones and their large size).

Correspondence to: Dr. Abdulaziz Al-Amri, The Department of Surgery, College of Medicine, King Khalid University, Abha, Saudi Arabia
Key Words: Extracorporeal shock wave lithotripsy - Renal stones - Stents - Bacteriuria.

\section{Introduction}

BACTERIURIA (i.e., the detection of 105 CFU per $\mathrm{ml}$ of urine on urine culture) has been found to be sequel of Extracorporeal Shock Wave Lithotripsy ESWL. This test is done routinely for patients undergoing ESWL three days prior to procedure. Therefore, antibiotic prophylaxis for patients undergoing ESWL is practiced in many centers to prevent development of urinary tract infections and its complications. This raised the question whether ESWL increases the incidence of bacteriuria in patients who had sterile urine to begin with [1-5]. However, a recent study concluded that there is no need for prophylactic antibiotics in renal stone patients undergoing ESWL if the urine culture is sterile [6]

In patients with ureteric or renal stone who have ureteric stent, it has been reported that the incidence of bacteriuria is expected to be higher as it is considered a foreign body. In patients with indwelling ureteric stent, or JJ stent, bacterial colonization increases with the duration of stent [7]. JJ stent insertion is usually performed under complete aseptic conditions and keeping it inside the body prevents it from any external access of infection. Therefore, it has been postulated that colonization of ureteric stent usually occurs as a result of iatrogenic causes and rarely ascending infection $[8,9]$.

Several studies have been conducted to explore the incidence of bacteriuria in patients with ureteric stents, but there is limited research on the effect of ESWL on bacteriuria in those patients who have 
renal stones and indwelling ureteric stent. Ozgur et al., [10] found the incidence of bacterial colonization was $25 \%$ in more than six weeks of stent duration and lesser incidence with lesser duration. Moreno et al., [11] reported that incidence of bacteriuria in patients without risk factors to be $5.8 \%$. In their study, they included patients with ureteric stents and renal stone who had ESWL. No patients received antibiotics before the ESWL procedure. They concluded that the incidence of bacteriuria in patients with indwelling ureteric stent was lower than expected.

Urine culture is less sensitive in determining the real bacterial colonization of the indwelling ureteric stent compared to the results obtained from culturing of the stent itself. This could be explained by the phenomenon of biofilm formation on the surface of ureteral stent which sometimes harbors the bacteria which is undetected in urine culture [12].

The retrieval of bacteria from ureteral stent is sometimes difficult. To improve the diagnosis of ureteral stent colonization with bacteria, a new test was studied. Sonication is a method of exposure of JJ stent post-removal to low energy ultrasound to shed out the bacteria adherent to the ureteral stent. The incidence of development of bacteriuria in patients who had sterile urine before ureteric stent placement was $26 \%$ and this was much higher in those with bacteriuria before stenting $(p<0.001)$ [13].

Honey et al., [14] clarified the argument regarding use of antibiotic prophylaxis for patients undergoing ESWL. The main differences were noticed in the guidelines of European and American associations of urology. While the European guidelines restricted the indications of antibiotics prophylaxis for patients with ureteral stents and nephrostomy tube, the American guidelines recommended the use of empirical antibiotic prophylaxis for all patients undergoing ESWL. The incidence of urinary tract infection was noticed in $0.3 \%$ of study population, while asymptomatic bacteriuria was detected in $2.8 \%$ of the patients. These results were found to be matching with European Urology Association guidelines and contradicted the American Urology Association guidelines.

\section{Material and Methods}

This study was conducted in Aseer Central Hospital in Abha, Saudi Arabia, between January and August 2015. We prospectively recruited 126 adult patients who had previously inserted JJ stent for renal or ureteral stones. Patients with chronic medical diseases or comorbidity (e.g., diabetes mellitus or malignancy) and other associated risk factors (e.g., elderly patients) were excluded.

All patients had negative urine culture just before ESWL. Urine cultures were done immediately after ESWL and two weeks later to detect the presence of bacteriuria. Those who had one or two positive cultures for bacterial growth were labeled to be having bacteriuria after ESWL, while those with both negative cultures were labeled as negative for bacteriuria.

\section{Results}

Table (1) shows that 126 patients were included in the study (94 patients, $74.6 \%$ were males). Age of patients ranged between 18 and 50 years (Mean \pm SD: $42.0 \pm 8.8$ years). The number of stones was mainly single (93.7\%), with a mean size of stones of $1.7 \pm 0.7 \mathrm{~cm}$. Fragmented stone was present in $95.2 \%$ of cases. Most patients had one stent (95.2\%), while $4.8 \%$ had two stents. Silicon stents were present in $51.6 \%$ of patients while polyurethane stents were present in $48.4 \%$ of them. The mean duration of stent use was $54.3 \pm 11.4$ days. Bacteriuria was positive among 26 patients $(20.6 \%)$.

Table (1): Characteristics of study sample.

\begin{tabular}{|c|c|}
\hline Characteristics & Value \\
\hline \multicolumn{2}{|l|}{ Gender: } \\
\hline Male & $94(74.6 \%)$ \\
\hline Female & $32(25.4 \%)$ \\
\hline Age in years (mean $\pm \mathrm{SD})$ & $42.0 \pm 8.8$ \\
\hline \multicolumn{2}{|l|}{ No. of stones: } \\
\hline Single & $118(93.7 \%)$ \\
\hline Multiple & $8(6.3 \%)$ \\
\hline Size of stones in $\mathrm{cm}($ mean $\pm \mathrm{SD})$ & $1.7 \pm 0.7$ \\
\hline \multicolumn{2}{|l|}{ Fragmented stone: } \\
\hline Yes & $120(95.2 \%)$ \\
\hline No & $6 \quad(4.8 \%)$ \\
\hline \multicolumn{2}{|l|}{ No. of stents: } \\
\hline One & $120(95.2 \%)$ \\
\hline Two & $6 \quad(4.8 \%)$ \\
\hline \multicolumn{2}{|l|}{ Type of stent: } \\
\hline Polyurethane & $61(48.4 \%)$ \\
\hline Silicon & $65(51.6 \%)$ \\
\hline Duration of stent use in days (mean $\pm \mathrm{SD}$ ) & $54.3 \pm 11.4$ \\
\hline \multicolumn{2}{|l|}{ Bacteriuria: } \\
\hline Negative & 100 \\
\hline Positive & 26 \\
\hline
\end{tabular}

Table (2) shows that incidence of bacteriuria among females was significantly higher than that among males $(40.6 \%$ and $13.8 \%$, respectively, 
$p=0.002$ ). Bacteriuria did not differ significantly according to patients' age. Incidence of bacteriuria significantly increased with number and size of stones ( $p=0.009$ and $p=0.001$, respectively), however, it did not differ significantly according to occurrence of stone fragmentation. Incidence of bacteriuria increased significantly according to number of stents and their duration of use $(p=0.001$ for both), but did not differ significantly according to type of stent.

Table (2): Incidence of bacteriuria according to patients' characteristics.

\begin{tabular}{|c|c|c|c|}
\hline \multirow[b]{2}{*}{ Characteristics } & \multicolumn{2}{|c|}{ Bacteriuria } & \multirow{2}{*}{$\begin{array}{c}p- \\
\text { value }\end{array}$} \\
\hline & $\begin{array}{l}\text { Negative } \\
(\mathrm{n}=100)\end{array}$ & $\begin{array}{l}\text { Positive } \\
(\mathrm{n}=26)\end{array}$ & \\
\hline \multicolumn{4}{|l|}{ Gender: } \\
\hline Male & $81(86.2 \%)$ & $13(13.8 \%)$ & \\
\hline Female & $19(59.4 \%)$ & $13(40.6 \%)$ & 0.002 \\
\hline $\begin{array}{l}\text { - Age in years (mean } \\
\pm \text { SD) }\end{array}$ & $41.5 \pm 8.9$ & $43.8 \pm 8.8$ & 0.242 \\
\hline \multicolumn{4}{|l|}{ No. of stones: } \\
\hline Single & $97(82.2 \%)$ & $21(17.8 \%)$ & \\
\hline Multiple & $3(37.5 \%)$ & $5 \quad(62.5 \%)$ & 0.009 \\
\hline $\begin{array}{l}\text { - Size of stones in } \mathrm{cm} \\
(\text { mean } \pm \text { SD })\end{array}$ & $1.6 \pm 0.6$ & $2.2 \pm 0.6$ & $<0.001$ \\
\hline \multicolumn{4}{|l|}{ Fragmented stone: } \\
\hline Yes & $94(78.3 \%)$ & $26(21.7)$ & \\
\hline No & $6 \quad(100.0 \%)$ & $0 \quad(0.0 \%)$ & 0.201 \\
\hline \multicolumn{4}{|l|}{ No. of JJ stents: } \\
\hline One & $99(82.5 \%)$ & $21(17.5 \%)$ & \\
\hline Two & $1 \quad(16.7 \%)$ & $5 \quad(83.3 \%)$ & $<0.001$ \\
\hline \multicolumn{4}{|l|}{ Type of stent: } \\
\hline Polyurethane & $45(73.8 \%)$ & $16(26.2 \%)$ & \\
\hline Silicon & $55(84.6 \%)$ & $10(15.4 \%)$ & 0.133 \\
\hline $\begin{array}{l}\text { - Duration of stent in } \\
\text { days (mean } \pm \text { SD) }\end{array}$ & $45.4 \pm 11.4$ & $53.3 \pm 7.4$ & $<0.001$ \\
\hline
\end{tabular}

\section{Discussion}

This study showed that incidence of bacteriuria in patients with renal stones and ureteric stents after ESWL was $20.6 \%$. Significantly higher incidence rates of bacteriuria were associated with female patients, but did not differ significantly according to patients' age.

Our finding is comparable with those of several studies, which reported incidence of bacteriuria with among patients with ureteric stents who did not undergo ESWL. Altunal et al., [15] reported that $18 \%$ of patients with ureteric stents developed urinary tract infection. Kehinde et al., [16] reported a $42 \%$ incidence of bacteriuria on the day of stent removal. Moreover, Yeniyol et al., [9], reported that the incidence of bacteriuria in patients with
$\mathrm{JJ}$ stents who was $18 \%$ despite most of them did not undergo ESWL. However, they found no association between patients' gender and development of bacteriuria.

The higher incidence of bacteriuria in our female patients compared with male patients could be explained by the fact that there are some anatomical as well as hormonal factors which generally predispose females to urinary tract infection [17] .

Several studies reported higher incidence of bacteriuria among in older patients [7,9]. However, in our study, older age did not show a significant association with bacteriuria, probably because our study sample included did not include patients with chronic diseases or associated comorbidity as well as the exclusion of elderly patients.

Our study revealed significantly higher incidence rates of bacteriuria were associated with number of stents and their duration of use.

These findings are in accordance with those of Ozgur et al., [10], who reported that bacteriuria was higher in patients with two stents, rather than those with single stents, which is explained by the provided bigger surface for biofilm development. Therefore, more adherent bacteria will be available for shedding in the urine followed by increase in bacteriuria.

Moreover, Altunal et al., [15] stated that the longer the duration of the stent, the higher the incidence of bacteriuria. Availability of the tube surface for bacteria for longer period can explain the mechanism of increase bacterial biofilming of tube surfaces.

Lojanapiwat [12] noted that the longer the duration of ureteral stent, the higher the incidence of bacteriuria. In stents' durations less than a month, the rate of bacteriuria was $33 \%$, while the highest incidence of bacterial colonization of ureteric stent reached $54 \%$ in patients with durations of stents more than 6 weeks.

Our study did not show statistically significant difference between silicone and polyurethane types of stents in the incidence of bacteriuria. Nevertheless, Farsi et al., showed that silicone was associated with less incidence of bacteriuria than polyurethane [6]. The lack of difference between both types could be attributed to the fact that the duration of the stents use in our study was quite short (with a mean duration less than two months).

Findings of the present study revealed that higher numbers and bigger sizes of stones were 
significantly associated with bacteriuria following ESWL. This finding is in accordance with that of Holmgren et al., [18], who stated that usually the big stones are usually composed of magnesium, ammonium, and phosphate (MAP) which is an infected stone. Nevertheless, incidence of bacteriuria was not found to be increased in patients with successful stone fragmentation.

Moreno et al., [11] explained that, although ESWL is a non-invasive procedure, which is not supposed to cause bacteriuria in patients having sterile urine, its association with bacteriuria is supposed to be through the disintegration of stone biofilm and release of bacteria. This may explain the development of pyelonephritis after ESWL. Ureteral stents, in addition, is another source of biofilm formation and theoretically bacteria can be released as an effect of shockwave.

Lu et al., [19] noted that comparing patients undergoing ESWL with JJ stents and those without $\mathrm{JJ}$ stents revealed that incidence of bacteriuria in both groups was almost the same. Therefore, they stated that prophylactic antibiotics for patient with sterile urine before undergoing ESWL is not indicated.

In conclusion, this study detected that the incidence of bacteriuria following ESWL in patients with ureteric stent was $20.6 \%$, which is comparable with those by previous studies reporting bacteriuria in patients with ureteric stent who did not undergo ESWL. Therefore, antibiotic prophylaxis in patients with ureteric stents undergoing ESWL may not be necessary, except in certain cases, (i.e., female gender, several stents and their prolonged duration, as well as the multiple stones and their large size). However, bacteriuria was not associated with stent type or stone fragmentation.

\section{Study limitations:}

The present study did not have a control group (i.e., patients with ureteric stent and renal stone not undergoing ESWL). The non-compliance of several patients regarding collecting samples two weeks after ESWL led us to exclude them and to have a limited sample size in this study.

\section{References}

1- D'ADDESSI A., VITTORI M., RACIOPPI M., PINTO F., SACCO E. and BASSI P.: Complications of extracorporeal shock wave lithotripsy for urinary stones: To know and to manage them a review. The Scientific World Journal, 2012.

2- SKOLARIKOS A., ALIVIZATOS G. and de la ROSETTE J.: Extracorporeal Shock Wave Lithotripsy 25 Years Later:
Complications and Their Prevention. European Urology, 50: 981-990, 2006.

3- ISLAM M.A., SHAMEEM I.A., AHASAN D.N., CHOUDHURY G.M. and WAHAB M.A.: Necessity of antibiotics prophylaxis during extracorporeal shock wave lithotripsy. Mymensingh Med. J., 14 (1): 58-60, 2005.

4- BACH C., KARAOLIDES T. and BUCHHOLZ N.: Extracorporeal shock wave lithotripsy: What is new? Arab J. Urol., 10 (3): 289-295, 2012.

5- MARQUES A.G., PASTERNAK J., DAMASCENA M.D., FRANÇA C.N. and MARTINO M.D.: Performance of the dipstick screening test as a predictor of negative urine culture. Einstein (São Paulo), 15 (1): 34-9, 2017.

6- ABROL N.: Antibiotic prophylaxis before extracorporeal shock wave lithotripsy in patients with sterile urine: Routine or targeted. Indian Journal of Urology, 29 (3): 265, 2013.

7- SINGH I. and INDWELLING J.J.: Ureteral stents-A current perspective and review of literature. Indian Journal of Surgery, 65 (5): 405-412, 2003.

8- RIEDL C.R., PLAS E., HÜBNER W.A., ZIMMERL H., ULRICH W. and PFLÜGER H.: Bacterial colonization of ureteral stents. European Urology, 36 (1): 53-9, 1999.

9- YENIYOL C.Ö., TUNA A., YENER H., ZEYREK N., TILKI A. and COSKUNER A.: Bacterial colonization of double $\mathbf{J}$ stents and bacteriuria frequency. International urology and nephrology, Jun. 1, 34 (2): 199-202, 2002.

10- OZGUR B.C., EKıC1 M., YUCETURK C.N. and BAYRAK O.: Bacterial colonization of double $\mathrm{J}$ stents and bacteriuria frequency. The Kaohsiung Journal of Medical Sciences, Dec. 1, 29 (12): 658-61, 2013.

11- MORENO M., LIROLA M., TABAR G., BAENA G., TENZA T. and ENCINAS L.: Incidence of infectious complications after extracorporeal shock wave lithotripsy in patients without associated risk factors. Journal of Urology, 192: 1446-9, 2014.

12- LOJANAPIWAT B.: Colonization of internal ureteral stent and bacteriuria. World Journal of Urology, 24 (6): 681-3, 2006.

13- BONKAT G., RIEKEN M., RENTSCH C.A., WYLER S., FEIKE A., SCHÄFER J., GASSER T., TRAMPUZ A., BACHMANN A. and WIDMER A.F.: Improved detection of microbial ureteral stent colonisation by sonication. World Journal of Urology, 29 (1): 133-8, 2011.

14- HONEY R.J., ORDON M., GHICULETE D., WIESENTHAL J.D., KODAMA R. and PACE K.T.: A Prospective Study Examining the Incidence of Bacteriuria and Urinary Tract Infection After Shock Wave Lithotripsy with Targeted Antibiotic Prophylaxis. J. Urol., Jun., 189 (6): 2112-7, 2013.

15- ALTUNAL N., WILLKE A. and HAMZAOGLU O.: Ureteral stent infections: A prospective study. Braz. J. Infect. Dis., 21 (3): 361-4, 2017.

16- KEHINDE E.O., ROTIMI V.O., AL-HUNAYAN A., ABDUL-HALIM H., BOLAND F. and AL-AWADI K.A. Bacteriology of urinary tract infection associated with indwelling J. ureteral stents. J. Endourol., 18 (9): 891-6, 2004. 
17- WEIN A.J., KAVOUSSI L.R., NOVICK A.C., PARTIN A.W. and PETERS C.A.: Editors. Campbell-Walsh Urology. 10th ed. Philadelphia: Saunders, 2012.

18- HOLMGREN K., DANIELSON B.G., FELLSTRÖM B., LJUNGHALL S., NIKLASSON F. and WIKSTRÖM B.: The relation between urinary tract infections and stone composition in renal stone formers. Scandinavian
Journal of Urology and Nephrology, Jan. 1, 23 (2): 1316,1989 .

19-LU Y., TIANYON F., PING H., LIANGЮN L., HAICHOA Y. and QIANG W.: Antibiotic prophylaxis for shock wave lithotripsy in patients with sterile urine before treatment may be unnecessary: A systemic review and meta-analysis. J. Urol., 188 (2): 441-8, 2012.

\section{نسبة حلدوث بكتيريا بالبول لدى المرضى البالغين

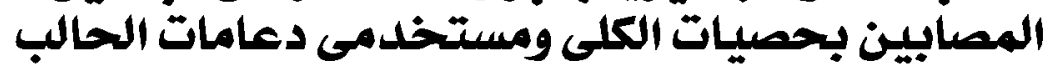

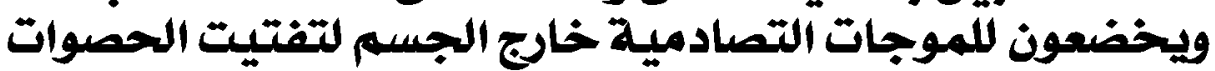

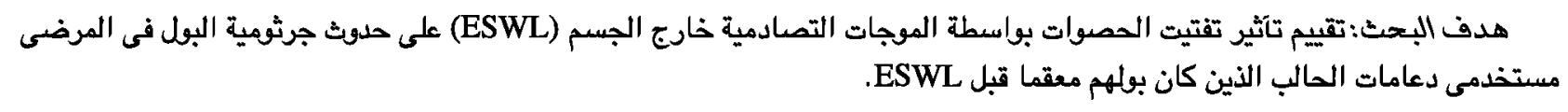

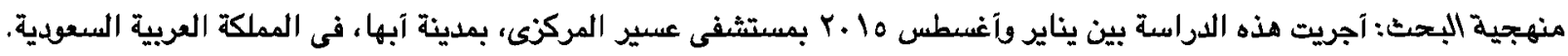

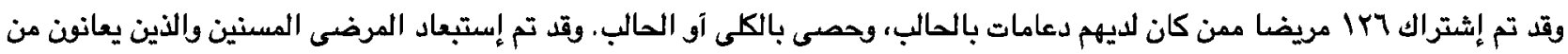

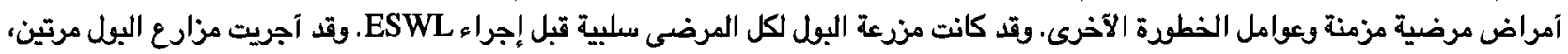

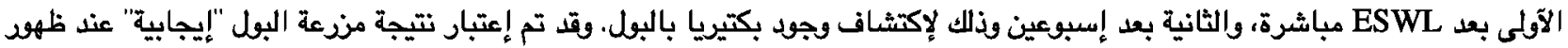

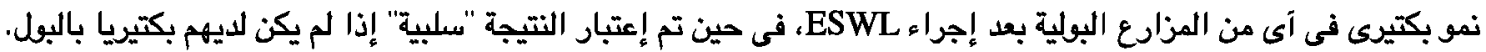

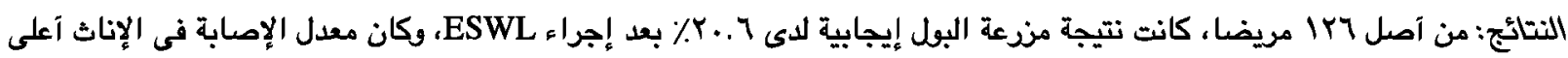

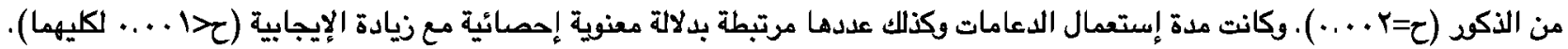

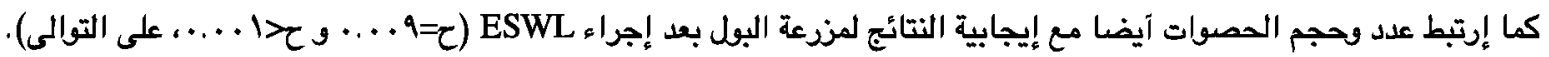

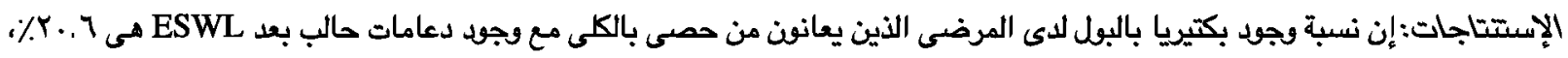

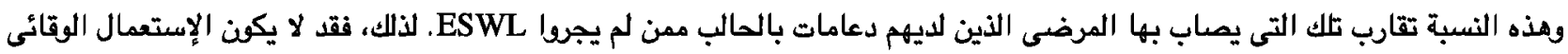

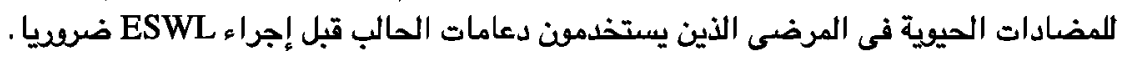

